\title{
ANALISIS STRATEGI PEMASARAN BIRO PERJALANAN WISATA CV. SKR TOUR \& TRAVEL DI ERA NEW NORMAL
}

\author{
Mira Fitriana ${ }^{1}$, Rieska Ernawati ${ }^{\star}{ }^{\star}$, Pertiwi Kusuma Astuti ${ }^{3}$ \\ ${ }_{1}^{1}$ Program Studi Arsitektur, Fakultas Teknik dan Rekayasa, Universitas Selamat Sri \\ 2 Program Studi Teknik Industri, Fakultas Teknik dan Rekayasa, Universitas Selamat Sri \\ ${ }^{3}$ Program Studi Teknik Sipil, Fakultas Teknik dan Rekayasa, Universitas Selamat Sri \\ Email:mira.fitrianaa@gmail.com; ernawatirieska@gmail.com; pertiwikusumaastuti@gmail.com
}

Artikel masuk : 31-10-2021

Artikel direvisi : 01-12-2021

Artikel diterima : 13-12-2021

${ }^{*}$ Penulis Korespondensi

\begin{abstract}
Abstrak -- CV. SKR Tour \& Travel merupakan bentuk usaha bisnis yang bergerak dibidang penyedia jasa layanan pariwisata. Sejak munculnya pandemi virus covid-19 di Indonesia pada awal tahun 2020 membawa dampak terhadap menurunnya omset yang diperoleh oleh CV SKR Tour \& Travel. Hal ini disebabkan karena adanya kebijakan pembatasan sosial berskala besar yang diterapkan oleh Pemerintah untuk menekan penyebaran virus di beberapa daerah khususnya Pulau Jawa. Kebijakan pembatasan sosial berskala besar ini mengakibatkan tempat wisata ditutup sehingga CV. SKR Tour \& Travel menjadi tidak beroperasi dan kehilangan pemasukan. Pemerintah mulai mencabut aturan pembatasan sosial berskala besar sehingga tempat wisata yang awalnya tidak beroperasi, akhirnya kembali beroperasi dengan syarat menerapkan protokol kesehatan. Dengan beroperasinya kembali tempat wisata maka CV SKR Tour \& Travel dapat memberikan jasa pelayanannya di bidang pariwisata. Berdasarkan kondisi tersebut maka perlu direncanakan strategi pemasaran guna menaikkan omset CV SKR Tour \& Travel. Salah satu cara untuk merencanakan strategi pemasaran dengan mengidentifikasi faktor internal dan eksternal perusahaan kemudian dianalisis dengan merumuskan beberapa strategi alternatif melalui analisis matriks SWOT dan dievaluasi melalui metode QSPM, CPM dan SPACE untuk mendapatkan prioritas strategi pemasaran. Prioritas strategi pemasaran dengan skor tertinggi 5.35 adalah memanfaatkan media sosial sebagai sarana promosi paket wisata yang beragam dari CV SKR Tour \& Travel.
\end{abstract}

Kata kunci: Pemasaran; CPM; QSPM; SPACE; SWOT

\begin{abstract}
CV. SKR Tour \& Travel is a form of business, a business engaged in tourism service providers. Since the emergence of the covid-19 virus pandemic in Indonesia in early 2020, it has impacted the decrease in turnover obtained by CV SKR Tour \& Travel. This is due to the large-scale social restriction policy implemented by the Government to suppress the spread of the virus in some areas, especially Java Island. This large-scale social restriction policy resulted in tourist attractions closing so that CV. SKR Tour \& Travel became out of service and lost revenue. The Government began lifting large-scale social restrictions so that tourist attractions that were not initially working eventually returned to operation on implementing health protocols. With the re-operation of tourist attractions, CV SKR Tour \& Travel can offer its services in tourism. Based on these conditions, it is necessary to plan a marketing strategy to increase the turnover of CV SKR Tour Travel. One way to plan a marketing strategy is by identifying the company's internal and external factors, then analysing by formulating several alternative strategies through SWOT matrix analysis and evaluating through the QSPM, CPM and SPACE methods to get marketing strategy priorities. The priority of marketing strategy with the highest score of 5.35 is to use social media to promote diverse tour packages from CV SKR Tour \& TravelUKM Yasin through the highest Human Error Probability (HEP) value is 0.544, which is found in the brick burning process.
\end{abstract}

Keywords: Marketing; CPM; QSPM; SPACE; SWOT 


\section{PENDAHULUAN}

Dunia pariwisata mengalami perkembangan yang pesat dengan menawarkan keindahan alam dan wisata budaya. Kekayaan alam dan wisata budaya dapat dinikmati oleh wisatawan sehingga mendukung pertumbuhan pariwisata. Berkat kerja keras baik dari pemerintah, pihak swasta, maupun masyarakat pada umumnya, pariwisata Indonesia dapat berkembang dengan baik. Keindahan yang dimiliki Indonesia menjadikan sebagai salah satu destinasi wisata dunia. Perkembangan dunia pariwisata sejalan dengan tumbuhnya bisnis di bidang penyedia jasa perjalanan pariwisata. Dunia usaha pariwisata yang banyak dikelola pihak swasta mampu mendorong peningkatan kunjungan wisatawan mancanegara dan menggerakkan wisatawan nusantara.

Di awal tahun 2020 pada bulan Februari pariwisata mengalami penurunan karena adanya dampak dari pencegahan penyebaran virus covid19. Pemerintah menerapkan aturan pembatasan sosial berskala besar di beberapa kota-kota besar di Indonesia, sehingga di awal tahun ini beberapa tempat wisata harus ditutup sementara. Adanya penutupan tersebut berdampak pada tidak beroperasinya biro perjalanan pariwisata. Pada pertengahan tahun 2020 pemerintah mulai melonggarkan aturan dengan mencabut kebijakan pembatasan sosial berskala besar, sehingga beberapa tempat wisata sudah dibuka kembali.

Sejak awal terjadinya pandemi covid-19 menyebabkan salah satu biro perjalanan pariwisata CV SKR Tour \& Travel yang berlokasi di Kendal terkena dampak dan tidak beroperasi sementara. Kebijakan pembatasan sosial berskala besar telah ditarik kembali namun minat masyarakat berwisata dengan menggunakan jasa biro perjalanan pariwisata belum nampak. Pada saat pandemi covid-19 belum terjadi, dalam 1 minggu CV SKR Tour \& Travel bisa melayani ratarata 4-5 perjalanan wisata, tetapi dari Februari hingga Oktober 2020 baru melayani 2 perjalanan wisata. Hal tersebut menunjukkan adanya penurunan omset yang signifikan. Berdasarkan hal itu guna meningkatkan permintaan dan minat masyarakat terhadap jasa penyedia biro perjalanan wisata maka perlu diketahui strategi pemasaran yang tepat digunakan oleh CV SKR Tour dimasa New Normal.

Strategi pemasaran merupakan model perencanaan pemasaran dalam mencapai tujuan yang hendak dicapai. Strategi tersebut dapat menetapkan target pasar yang hendak dituju dan penetapan bauran terkait pemasaran (Setyorini et al., 2016). Pemasaran adalah implementasi program organisasi dan pengendalian yang dirancang untuk menciptakan, membangun, dan memelihara pemilihan pasar sasaran, analisis pasar sasaran, fragmentasi perencanaan, dan pertukaran yang menguntungkan dari pangsa pasar tertentu bagi organisasi (Prayudi \& Yulistria, 2020).

Ada beberapa metode yang terdapat dalam strategi pemasaran diantaranya analisis SWOT, metode Quantitative Strategic Planning Matrix (QSPM), Competitive Profile Matrix (CPM) dan Strategic Position and Action Evaluation (SPACE). Analisis SWOT bertujuan mengidentifikasi kekuatan internal, peluang maupun ancaman eksternal dan kekuatan internal (Akbar, 2018). Metode QSPM merupakan teknik analisis dengan strategi terbaik untuk menentukan daya Tarik relatif (Tambunan et al., 2019). Matriks SPACE menunjukkan pemilihan kuadran strategi yang sesuai dengan kondisi perusahaan yang meliputi strategi kompetitif, agresif, defensive atau konservatif (Tambunan et al., 2019). Matriks CPM digunakan untuk mengidentifikasi kelemahan dan keunggulan perusahaan terkait dengan harga, promosi, tempat dan produk (Tambunan et al., 2019). Penelitian ini menggabungkan keempat metode untuk memperoleh strategi pemasaran yang sesuai dengan CV SKR Tour \& Travel.

State of the art penelitian pada bidang yang telah diteliti sebelumnya sebagai berikut, Tarigan et al. (2015) meneliti mengenai strategi pemasaran paket wisata dengan menggunakan SWOT kemudian Akbar (2018) juga meneliti strategi pemasaran dengan SWOT namun dengan menambah variabel performance kerja dalam penelitiannya. Hartati (2016) meneliti strategi pemasaran di perusahaan produsen roti dengan menggunakan analisis SWOT dan dibantu dengan tools diagram fishbone. Penelitian Setyorini et al. (2016) tidak hanya menggunakan analisis SWOT tetapi juga ditambahkan metode QSPM dalam strategi pemasarannya. Penelitian lain mengenai strategi pemasaran dikemukakan juga oleh Wicaksono (2018) dengan menggunakan analisis SWOT tanpa menggunakan skala industri. Penelitian oleh Tambunan et al. (2019) mengenai perencanaan strategi menggunakan tiga metode yaitu QSPM, CPM dan SPACE. Adanya enam penelitian terdahulu maka penelitian ini mengkombinasikan antara analisis SWOT, metode QSPM, metode CPM dan metode SPACE.

\section{METODE PENELITIAN}

Metode penelitian menjelaskan mengenai tahapan penggunaan seluruh metode dalam penentuan strategi pemasaran. Gambar $1 \mathrm{mem}$ berikan gambaran tahapan penggunaan metode strategi pemasaran mulai dari input stage hingga evaluation alternative. 


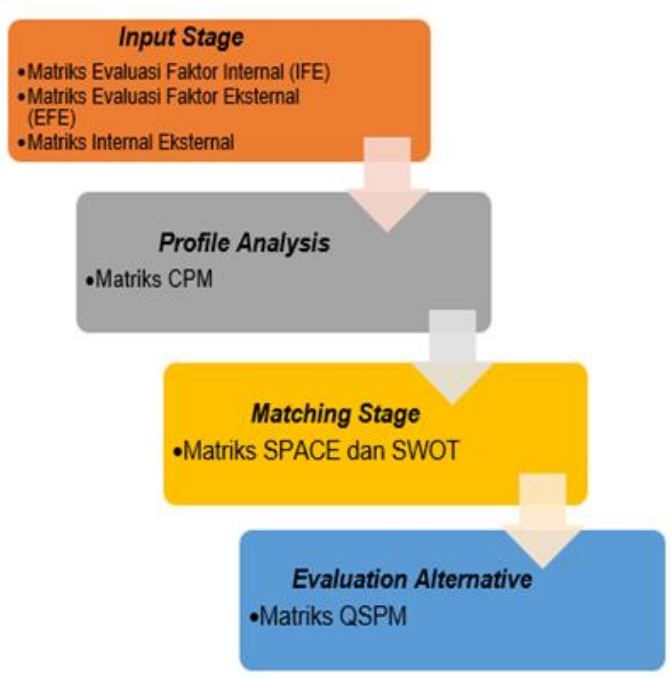

Gambar 1. Tahapan Penggunaan Metode

Tahap awal dimulai input stage yang menyajikan matriks evaluasi faktor eksternal, faktor internal dan matriks evaluasi faktor eksternal dan matriks internal dan eksternal. Matriks evaluasi faktor internal terdiri dari faktor kekuatan dan kelemahan. Matriks evaluasi faktor eksternal terdiri dari faktor peluang dan ancaman. Keseluruhan faktor diberi rating dan bobot kemudian dikalikan menjadi skor. Total skor baik dari matriks evaluasi faktor internal dan eksternal diinput ke dalam matriks internal eksternal. Hasil kedua skor tersebut dipertemukan dalam sebuah titik dimana letak titik menunjukkan posisi. Terdapat 9 posisi didalamnya yang dikategorikan menjadi pertumbuhan, stabilisasi, atau divestasi. Hal ini berkaitan dengan penentuan tujuan bisnis serta menganalisa faktor internal dan eksternal yang menunjang pencapaian tujuan yang ditetapkan (Akbar, 2018)

Tahap kedua adalah profile analysis dimana menggunakan matriks CPM. Matriks CPM memberikan gambaran titik kuat dan titik lemah relatif suatu produk atau jasa dibandingkan kompetitor (Harisudin, 2011). Matriks CPM digunakan untuk membandingan dengan beberapa pesaing. Langkah pertama menentukan faktorfaktor yang akan diberi bobot dan rating. Rating diambil berdasarkan hasil kuesioner dari customer yang pernah menggunakan jasa tour \& travel baik pesaing maupun pengguna CV SKR Tour \& Travel sendiri. Total skor terbanyak menunjukkan bahwa penyedia jasa tour \& travel tersebut unggul dibanding pesaing yang lain.

Matching stage merupakan tahap pencocokan antara strategi yang diperoleh dari matriks SPACE dan matriks SWOT. Matriks SPACE memberikan pemilihan kerangka empat kuadran sesuai dengan kondisi proses bisnis organisasi (Rachmawati \& Pratama, 2017).
Sebelum menentukan matriks SPACE dibuat terlebih dahulu grafik. Dari grafik tersebut akan diketahui strategi yang sesuai dengan berdasarkan dimensi-dimensi yang digunakan di dalamnya. Matriks SWOT dibuat berdasarkan hasil dari posisi strategi sesuai matriks internal dan eksternal. Adanya alternatif strategi yang diperoleh dari hasil matriks SWOT maupun SPACE maka dibuat tabel pencocokan untuk mencocokkan antara kesesuaian alternatif strategi sehingga alternatif strategi mengerucut pada beberapa strategi saja.

Pengolahan data yang digunakan matriks ini menggunakan analisis penggabungan pada setiap tahap sehingga alternative perumusan strategi yang ditentukan merupakan hasil pengolahan dari tahap-tahap sebelumnya (Abdiputra, 2020). Beberapa alternatif strategi pilihan yang diperoleh dari hasil matriks SWOT dan SPACE digunakan untuk pengolahan matriks QSPM. Matriks QSPM berguna dalam menentukan alternatif strategi terbaik diantara alternatif strategi yang lain. Penggunaan matriks QSPM memberikan keuntungan dalam proses pemeriksaan strategi-strategi secara berurutan dan bersamaan (Zulkarnaen \& Sutopo, 2013). Matriks QSPM terdiri dari seluruh faktor SWOT, bobot, skor daya Tarik (AS) dan Total Attractiveness Score (TAS). TAS diperoleh dengan mengalikan bobot dengan AS. Keseluruhan TAS masing-masing alternatif strategi ditotal lalu total skor yang tertinggi menjadi dasar keputusan untuk memilih alternatif strategi terbaik

\section{HASIL DAN PEMBAHASAN}

CV. SKR Tour and Travel bergerak di bidang jasa transportasi khusus pariwisata. CV. SKR Tour and Travel berdiri sejak 07 November 2015. Sejak saat itu perusahaan mulai membuka pelayanan perjalanan wisata. Pada tahun 2016 perusahaan mulai bekerja sama dengan agen bis, hotel, dan katering makanan. Pada tahun tersebut CV. SKR Tour and Travel menguasai dalam segala hal mulai dari pemesanan bus hingga memandu tour. Pada tahun 2017 perusahaan mulai membuka lowongan pekerjaan seiring dengan perkembangan peningkatan konsumen. CV. SKR Tour and Travel pada tahun 2018 memiliki banyak Freelance Tour Leader untuk melaksanakan perjalanan wisata bersama konsumennya. Lokasi CV. SKR Tour and Traveldi JI JL. Soekarno Hatta No.228, Ketapang 16/05 Kendal, Jawa Tengah di bawah kepemimpinan Muhammad Syaefudin selaku Direktur sekaligus Owner dengan dibantu oleh beberapa orang staff.

Hasil dan pembahasan menggunakan pengolahan dengan matriks yang berupa matriks evaluasi faktor internal, matriks evaluasi faktor 
eksternal, CPM, SWOT, SPACE dan QSPM. Responden dipilih secara purposive sebanyak tiga orang, yaitu berasal dari staff pemasaran CV SKR Tour \& Travel. Pemilihan responden didasarkan pengetahuan informasi tentang faktor strategi internal dan eksternal serta berperan dalam merumuskan strategi pemasaran dan memasarkan produk dan mengetahui kondisi perusahaan secara menyeluruh.

\section{Input Stage}

Tahap ini merupakan tahap input berupa seluruh faktor pada matriks internal dan eksternal. Tabel 1 merupakan tabel matriks faktor internal.

Tabel 1. Matriks IFE CV SKR Tour \& Travel

\begin{tabular}{|c|c|c|c|c|}
\hline & Kekuatan & Bobo & Zating & $\begin{array}{l}\text { Skor } \\
\text { Total }\end{array}$ \\
\hline$\overline{1}$ & Produk & & & \\
\hline & Inovasi paket wisata baru & 0.08 & 4 & 0.310 \\
\hline 2 & $\begin{array}{l}\text { Memiliki value yang dibagikan } \\
\text { kepada peserta } \\
\text { Sdm }\end{array}$ & 0.08 & 4 & 0.310 \\
\hline & Semangat dan etos kerja baik & 0.08 & 3 & 0.233 \\
\hline & Generasi muda yang satu visi misi & 0.08 & 3 & 0.233 \\
\hline 3 & $\begin{array}{l}\text { Hubungan dengan relasi bisnis dan } \\
\text { rekan }\end{array}$ & & & \\
\hline & Modal sosial yang kuat & 0.08 & 3 & 0.233 \\
\hline & Jaringan yang cukup luas & 0.08 & 4 & 0.310 \\
\hline 4 & Kulture & & & \\
\hline & $\begin{array}{l}\text { Kultur organisasi yang } \\
\text { membangun, saling support }\end{array}$ & 0.08 & 3 & 0.233 \\
\hline & Mendukung keterbukaan & 0.06 & 3 & 0.181 \\
\hline & Kelemahan & & & \\
\hline$\overline{1}$ & Manajemen & & & \\
\hline & & 0.08 & 2 & 0.155 \\
\hline & Belum ada SOP & 0.08 & 1 & 0.078 \\
\hline 2 & Teknologi & & & \\
\hline & $\begin{array}{l}\text { Belum dikelola dengan baik meski } \\
\text { sudah ada (website, ig, fb) }\end{array}$ & 0.08 & 2 & 0.155 \\
\hline 3 & Keuangan & & & \\
\hline & Struktur modal kurang kuat & 0.05 & 2 & 0.103 \\
\hline 4 & Brand & & & \\
\hline & Belum kuat dan dikenal luas & 0.06 & 1 & 0.060 \\
\hline 5 & Promosi & & & \\
\hline & Bahan promosi masih terbatas & 0.05 & 2 & 0.103 \\
\hline & Total & 1.00 & & 2.698 \\
\hline
\end{tabular}

Matriks faktor internal terdiri dari faktor kekuatan dan faktor kelemahan. Pada tiap faktor diberi bobot dan rating dimana total bobot 1 dan pemberian rating skala 1 hingga 4 . Total skor untuk faktor kekuatan sebesar 2.043, sedangkan faktor kelemahan sebesar 0.654. Total keseluruhan matriks evaluasi internal sebesar 2.698. Hasil matriks evaluasi internal ini menunjukkan bahwa CV SKR Tour \& Travel memiliki dominansi faktor kekuatan daripada kelemahan.
Tabel 2. Matriks EFE CV SKR Tour \& Travel

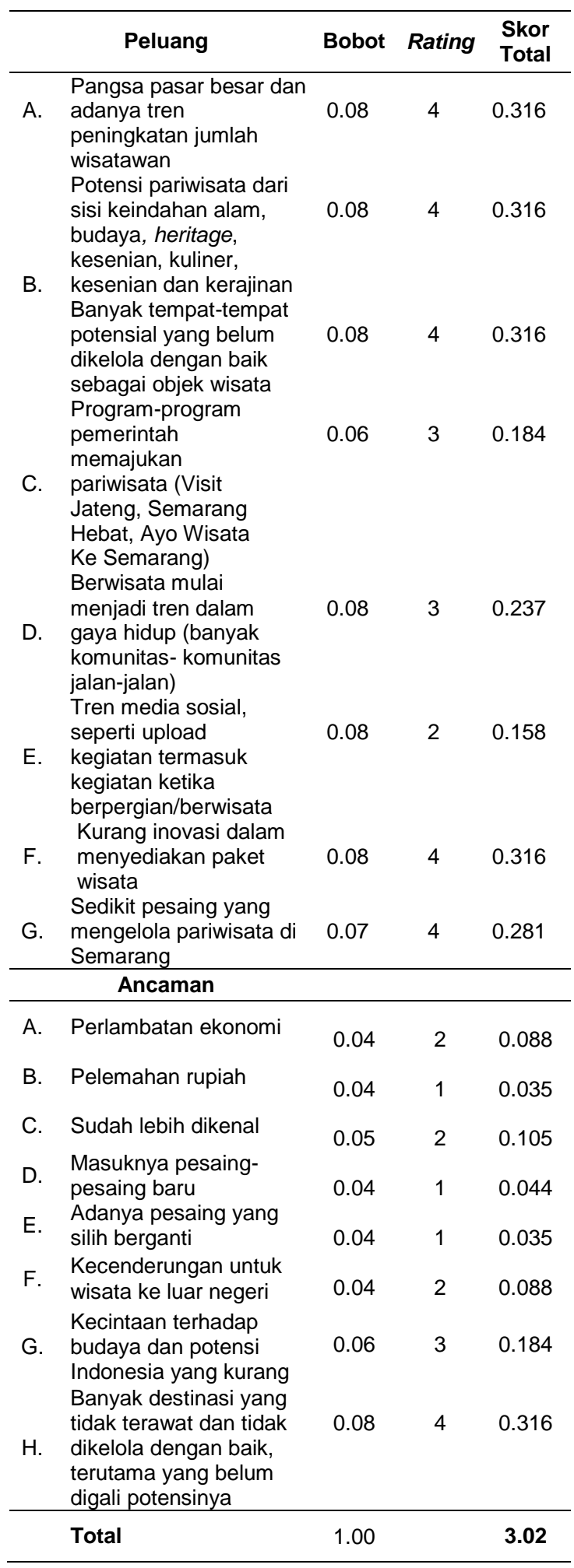

Tabel 2 merupakan tabel matriks faktor eksternal. Tabel matriks faktor eksternal terdiri dari faktor peluang dan ancaman. Skor pada faktor peluang sebesar 2.125, sedangkan skor pada faktor ancaman sebesar 0.895. Dari hasil 
tersebut menandakan bahwa peluang usaha lebih besar daripada ancaman yang dialami CV SKR Tour \& Travel. Total keseluruhan skor matriks faktor eksternal ini adalah 3.02 .

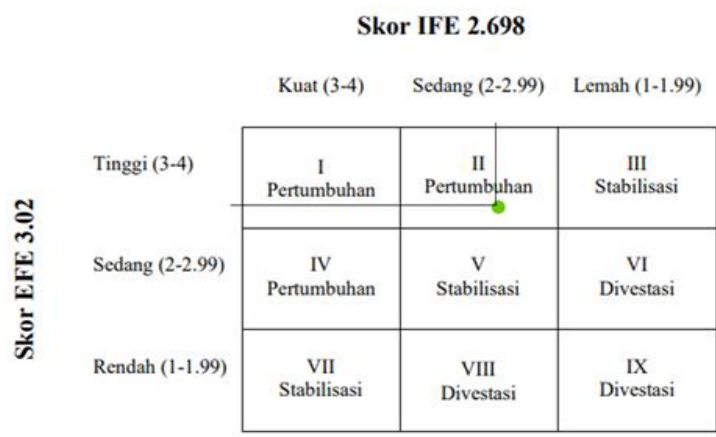

Gambar 2. Matriks IE CV SKR Tour \& Travel

Berdasarkan hasil total skor matrik IFE dan EFE pada Gambar 2, maka diperoleh titik pada grafik berada pada kuadran II Pertumbuhan. Hal ini menunjukkan bahwa CV SKR Tour \& Travel perlu menggunakan strategi mengembangkan dan menumbuhkan usahanya.

\section{Profile Analysis}

Tahap analisis profil dengan menggunakan bantuan matriks CPM dalam rangka mengidentifikasi pesaing CV SKR Tour \& Travel. Terdapat dua pesaing utama, yang diwakili dengan nama inisial A Tour dan B Tour. Diantara 2 pesaingnya CV SKR Tour \& Travel sedikit lebih unggul dibandingkan A Tour. Hasil perhitungan skor terlihat pada Tabel 3.

\section{Matching Stage}

Pada awal tahap matching stage dibuat lebih dahulu matriks SPACE. Matriks SPACE disusun berdasarkan dimensi internal dan eksternal. Dimensi internal terdiri dari Financial Strength (FS) dan Competitive Advantage (CA). Dimensi eksternal terdiri dari Environmental Stability (ES) dan Industry Strength (IS). Dari hasil nilai dimensi internal dan eksternal dapat diperoleh nilai $x$-axis dan $y$-axis sehingga dapat digambarkan pada grafik berikut dan dapat dikategorikan dalam strategi agresif yang dapat dilihat pada Gambar 3 grafik matriks SPACE.

Berdasarkan hasil analisis pada seluruh dimensi matriks SPACE baik internal maupun eksternal maka dapat disusun strategi yang sesuai seperti berikut ini: (a) Penetrasi Pasar (mengembangkan jaringan untuk memperbanyak konsumen); (b) Pengembangan Produk (menawarkan variasi paket wisata tiap periodik melalui media sosial; (c) Diversifikasi (menawarkan paket wisata yang lebih menarik dibanding pesaing); (d) Backward Integration (menjalin kerjasama dengan pemerintah dan pengusaha terkait; (e) Forward Integration (mengutamakan pelayanan) dan (f) Horizontal Integration (memberikan penawaran terbaik sehingga selalu menjadi pemenang tender).

Tabel 3. Matriks CPM

\begin{tabular}{|c|c|c|c|c|c|c|c|}
\hline \multirow{2}{*}{ Faktor Penentu Keberhasilan } & \multirow{2}{*}{ Bobot } & \multicolumn{2}{|c|}{$\begin{array}{c}\text { CV SKR Tour \& } \\
\text { Travel }\end{array}$} & \multicolumn{2}{|c|}{ A Tour } & \multicolumn{2}{|c|}{ B Tour } \\
\hline & & Rating & $\begin{array}{l}\text { Total } \\
\text { Skor }\end{array}$ & Rating & $\begin{array}{l}\text { Total } \\
\text { Skor }\end{array}$ & Rating & $\begin{array}{l}\text { Total } \\
\text { Skor }\end{array}$ \\
\hline $\begin{array}{l}\text { Pelayanan sebelum } \\
\text { pemesanan wisata }\end{array}$ & 0.08 & 3.85 & 0.308 & 3.75 & 0.3 & 3.45 & 0.276 \\
\hline Variasi paket wisata & 0.05 & 3.25 & 0.1625 & 3.5 & 0.175 & 3.35 & 0.1675 \\
\hline Promosi paket wisata & 0.19 & 3.5 & 0.665 & 3.15 & 0.5985 & 3.25 & 0.6175 \\
\hline Daya saing harga & 0.17 & 3.75 & 0.6375 & 3.5 & 0.595 & 3.5 & 0.595 \\
\hline Travel yang lebih dikenal & 0.09 & 3.35 & 0.3015 & 3.25 & 0.2925 & 3.25 & 0.2925 \\
\hline Loyalitas konsumen & 0.07 & 3.5 & 0.245 & 3.25 & 0.2275 & 2.95 & 0.2065 \\
\hline $\begin{array}{l}\text { Kehandalan transportasi yang } \\
\text { digunakan }\end{array}$ & 0.13 & 3.35 & 0.4355 & 3.35 & 0.4355 & 3.25 & 0.4225 \\
\hline Ketepatan waktu & 0.07 & 3.25 & 0.2275 & 3.5 & 0.245 & 3.25 & 0.2275 \\
\hline \multirow[t]{2}{*}{$\begin{array}{l}\text { Pelayanan dan kecakapan tour } \\
\text { leader }\end{array}$} & 0.15 & 3.75 & 0.5625 & 3.65 & 0.5475 & 3.35 & 0.5025 \\
\hline & 1 & & 3.545 & & 3.4165 & & 3.3075 \\
\hline
\end{tabular}




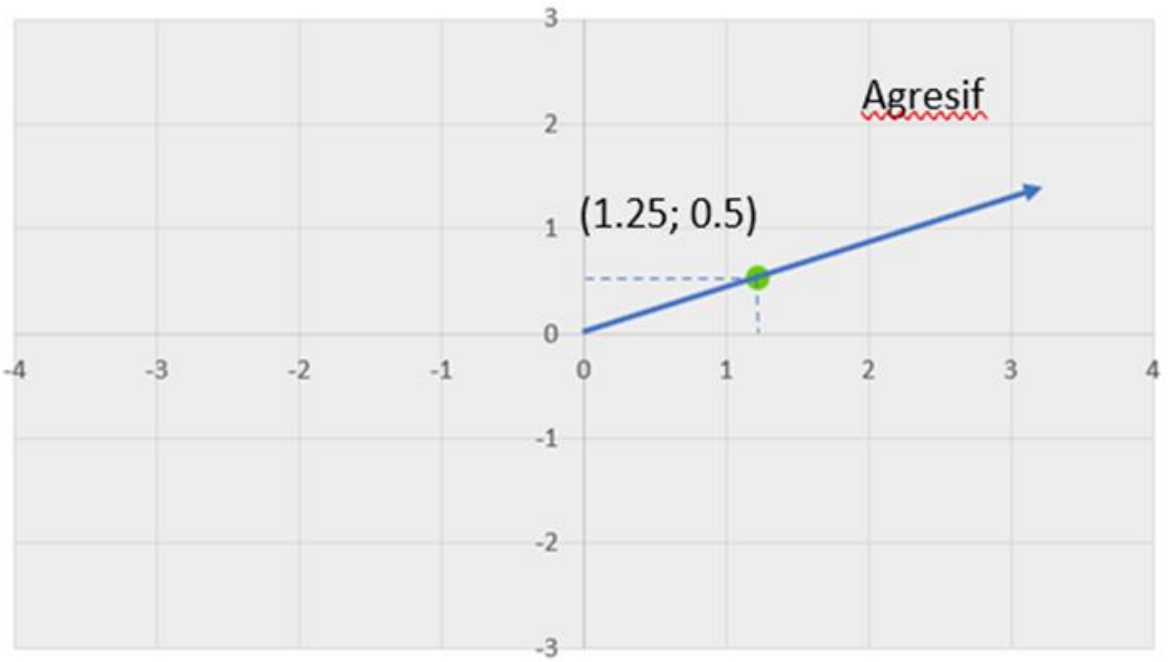

Gambar 3. Grafik Matriks SPACE

Tahap selanjutnya adalah penentuan matriks SWOT. Semua organisasi membutuhkan pemasaran untuk mencapai tujuan sehingga untuk dapat mewujudkannya maka perlu diterapkan suatu strategi yang tepat dengan menggunakan SWOT (Wicaksono, 2018). Berikut ini merupakan uraian mengenai SWOT:

1. Meningkatkan variasi penawaran paket wisata

2. Memanfaatkan jaringan yang dimiliki

3. Mengelola media social dengan baik

4. Memanfaatkan media sosial sebagai media promosi dengan maksimal

5. Melihat keunggulan pesaing sebagai bahan evaluasi

6. Memperkuat jaringan untuk mengalahkan pesaing

7. Membenahi manajemen pengelolaan secara keseluruhan

8. Memberikan alternatif-alternatif destinasi

Penyesuaian antara strategi dari matriks

SPACE dan SWOT dilakukan dengan mencocokan melalui korelasi sehingga diperoleh 3 alternatif dalam upaya strategi pemasaran CV SKR Tour \& Travel (Tabel 4).

Tabel 4. Pencocokan SWOT dan SPACE

\begin{tabular}{|c|c|c|c|c|c|c|c|c|c|}
\hline \multirow{8}{*}{ 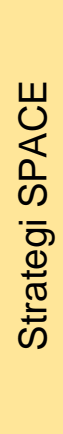 } & & \multicolumn{8}{|c|}{ Strategi SWOT } \\
\hline & & 1 & 2 & 3 & 4 & 5 & 6 & 7 & 8 \\
\hline & A & & & & & & $\sqrt{ }$ & & \\
\hline & $B$ & & & & $\sqrt{ }$ & & & & \\
\hline & C & & & & & & & & $\sqrt{ }$ \\
\hline & D & & & & & & & & \\
\hline & $E$ & & & & & & & & \\
\hline & $\mathrm{F}$ & & & & & & & & \\
\hline
\end{tabular}

Hasil kombinasi antara SWOT dan SPACE diperoleh tiga strategi yaitu:

1. Strategi 1: Memperluas jaringan untuk mengungguli pesaing dan memperbanyak konsumen

2. Strategi 2: Menawarkan beraneka ragam paket wisata dengan memanfaatkan media sosial sebagai sarana promosi

3. Strategi 3: Memberikan penawaran destinasi wisata menarik terlebih lagi yang sedang viral

\section{Evaluation Alternative}

Tahap evaluasi ini menggunakan metode QSPM. Adanya 3 alternatif strategi yang diperoleh pada tahap pencocokan digunakan sebagai evaluasi dalam matriks QSPM. Setelah mengembangkan sejumlah alternatif strategi, perusahaan harus mampu mengevaluasi dan kemudian memilih strategi yang terbaik yang paling cocok dengan kondisi internal perusahaan serta lingkungan eksternal (Puspitasari et al., 2013). Alternatif strategi yang telah ditentukan sebelumnya dapat digunakan untuk memudahkan pengambilan keputusan alternatif terbaik.

Berdasarkan hasil matriks QSPM (Tabel 5) maka alternatif 2 memiliki skor tertinggi dan menjadi strategi yang paling utama. Alternatif 2 merupakan strategi pemasaran dengan menawarkan beraneka ragam paket wisata dengan memanfaatkan media sosial sebagai sarana promosi. Pemanfaatan media sosial seperti memasang iklan pada seluruh platform media social, memasang adsense di youtube, endorse paket wisata dengan menggaet influencer local dari area Kendal dan Semarang, membuat website yang menampilkan segala informasi penawaran paket wisata dengan tampilan menarik dan user friendly, menerapkan strategi one day 
one posting promosi di semua platform media sosial secara periodik dan disesuaikan kontennya dengan apa yang sedang tren atau viral saat itu.

Dunia maya selain mampu menghubungkan orang dengan perangkat, juga menghubungkan orang dengan orang lain di seluruh penjuru dunia (Mustika, 2019). Melihat hal ini, dapat disimpulkan bahwa potensi digital marketing di Indonesia masih sangat besar (Sulaksono, 2020). Strategi digital marketing ini lebih prospektif karena memungkinkan para calon pelanggan potensial untuk memperoleh segala macam informasi mengenai produk dan bertransaksi melalui internet (Purwana et al., 2017). Media sosial merupakan sarana digital marketing yang paling mudah untuk dimanfaatkan saat ini (Hadi \& Zakiah, 2021). Pemasaran produk menggunakan digital marketing dan memanfaatkan media sosial untuk dapat menjangkau konsumennya secara langsung dan dapat menekan biaya promosi (Hardilawati, 2020).

CV SKR Tour \& Travel saat ini mulai fokus pada penawaran variasi paket wisata dengan menggunakan media sosial sebagai sarana promosi. Adanya media sosial telah meningkatkan omset perusahaan, dan terjadi peningkatan minat wisata dengan menggunakan jasa CV SKR Tour \& Travel.

Tabel 5. Matriks QSPM

\begin{tabular}{|c|c|c|c|c|c|c|c|c|}
\hline \multirow{2}{*}{\multicolumn{2}{|c|}{ Faktor }} & \multirow{2}{*}{ Bobot } & \multicolumn{2}{|c|}{ Strategi 1} & \multicolumn{2}{|c|}{ Strategi 2} & \multicolumn{2}{|c|}{ Strategi 3} \\
\hline & & & AS & TAS & AS & TAS & AS & TAS \\
\hline \multirow[t]{8}{*}{$\bar{S}$} & 1 & 0.08 & 4 & 0.31 & 3 & 0.23 & 2 & 0.16 \\
\hline & 2 & 0.08 & 4 & 0.31 & 3 & 0.23 & 2 & 0.16 \\
\hline & 3 & 0.08 & 2 & 0.16 & 3 & 0.23 & 1 & 0.08 \\
\hline & 4 & 0.08 & 2 & 0.16 & 3 & 0.23 & 1 & 0.08 \\
\hline & 5 & 0.08 & 1 & 0.08 & 3 & 0.23 & 4 & 0.31 \\
\hline & 6 & 0.08 & 2 & 0.16 & 4 & 0.31 & 3 & 0.23 \\
\hline & 7 & 0.08 & 1 & 0.08 & 3 & 0.23 & 2 & 0.16 \\
\hline & 8 & 0.06 & 2 & 0.12 & 1 & 0.06 & 1 & 0.06 \\
\hline \multirow[t]{6}{*}{ W } & 1 & 0.08 & 1 & 0.08 & 1 & 0.08 & 1 & 0.08 \\
\hline & 2 & 0.08 & 1 & 0.08 & 1 & 0.08 & 1 & 0.08 \\
\hline & 3 & 0.08 & 1 & 0.08 & 3 & 0.24 & 1 & 0.08 \\
\hline & 4 & 0.05 & 1 & 0.05 & 3 & 0.15 & 1 & 0.05 \\
\hline & 5 & 0.06 & 1 & 0.06 & 4 & 0.24 & 1 & 0.06 \\
\hline & 6 & 0.05 & 3 & 0.15 & 4 & 0.20 & 1 & 0.05 \\
\hline \multirow[t]{8}{*}{0} & 1 & 0.08 & 3 & 0.24 & 4 & 0.32 & 1 & 0.08 \\
\hline & 2 & 0.08 & 4 & 0.32 & 3 & 0.24 & 2 & 0.16 \\
\hline & 3 & 0.08 & 3 & 0.24 & 1 & 0.08 & 4 & 0.32 \\
\hline & 4 & 0.06 & 1 & 0.06 & 2 & 0.12 & 3 & 0.18 \\
\hline & 5 & 0.08 & 3 & 0.24 & 4 & 0.32 & 1 & 0.08 \\
\hline & 6 & 0.08 & 1 & 0.08 & 4 & 0.32 & 1 & 0.08 \\
\hline & 7 & 0.08 & 4 & 0.32 & 3 & 0.24 & 1 & 0.08 \\
\hline & 8 & 0.07 & 3 & 0.21 & 1 & 0.07 & 4 & 0.28 \\
\hline \multirow[t]{8}{*}{$\mathbf{T}$} & 1 & 0.04 & 2 & 0.08 & 1 & 0.04 & 1 & 0.04 \\
\hline & 2 & 0.04 & 2 & 0.08 & 1 & 0.04 & 1 & 0.04 \\
\hline & 3 & 0.05 & 3 & 0.15 & 4 & 0.20 & 1 & 0.05 \\
\hline & 4 & 0.04 & 4 & 0.16 & 3 & 0.12 & 1 & 0.04 \\
\hline & 5 & 0.04 & 4 & 0.16 & 3 & 0.12 & 1 & 0.04 \\
\hline & 6 & 0.04 & 4 & 0.16 & 3 & 0.12 & 1 & 0.04 \\
\hline & 7 & 0.06 & 4 & 0.24 & 3 & 0.18 & 2 & 0.12 \\
\hline & 8 & 0.06 & 1 & 0.06 & 1 & 0.06 & 4 & 0.24 \\
\hline \multicolumn{2}{|c|}{ TOTAL } & & & 4.66 & & 5.35 & & 3.49 \\
\hline
\end{tabular}




\section{KESIMPULAN}

Pada kondisi saat ini dimana pemerintah mulai memberikan izin untuk sektor wisata dapat beroperasi di era new normal seperti ini maka CV SKR Tour \& Travel berupaya mengupayakan peningkatan penjualan paket wisatanya. Dalam upaya tersebut maka disusun strategi pemasaran dengan berbagai tahapan penggunaan metode dari mulai input stage, profile analysis, matching stage dan evaluation alternative. Dari hasil pengolahan dan pembahasan diperoleh bahwa strategi yang paling utama adalah menawarkan beraneka ragam paket wisata dengan memanfaatkan media sosial sebagai sarana promosi. Penelitian selanjutnya dapat menentukan pemilihan strategi alternatif dengan menggunakan metode pengambilan keputusan multikriteria.

\section{DAFTAR PUSTAKA}

Abdiputra, Y. (2020). Strategi Pengembangan Usaha Bidang Bakery. Prosiding Seminar Nasional Fakultas Teknik Universitas Maarif Hasyim Latif Sidoarjo, 131-136. https://ejournal.umaha.ac.id/index.php/teknik/article/ view/688

Akbar, M. S. (2018). Analisa Strategi Pemasaran terhadap Performance Kerja dengan Menggunakan Metode Analisis SWOT (Studi Kasus: Pt. Dk). Ratih: Jurnal Rekayasa Teknologi Industri Hijau, 1(1), 1-14. https://ejournal.unugha.ac.id/index.php/ratih /article/view/64

Hadi, D. F., \& Zakiah, K. (2021). Strategi Digital Marketing Bagi UMKM (Usaha Mikro Kecil Menengah) untuk Bersaing di Era Pandemi_Strategi Digital Marketing Bagi UMKM (Usaha Mikro Kecil Menengah) untuk Bersaing di Era Pandemi. Competitive, 16(1), 32-41. https://ejurnal.poltekpos.ac.id/index.php/co mpetitive/article/view/1171

Hardilawati, W. laura. (2020). Strategi Bertahan UMKM di Tengah Pandemi Covid-19. Jurnal Akuntansi Dan Ekonomika, 10(1), 89-98. https://doi.org/10.37859/jae.v10i1.1934

Harisudin, M. (2011). Competitive profile matrix sebagai alat analisis strategi pemasaran produk atau jasa. Jurnal Sepa, 7(2), 80-84. https://jurnal.uns.ac.id/sepa/article/view/488 91

Hartati, M. H. (2016). Perancangan Strategi Pemasaran dengan Menggunakan Metode Swot di CV. Sekar Sari Roti Pekanbaru. Jurnal Teknik Industri: Jurnal Hasil Penelitian Dan Karya IImiah Dalam Bidang Teknik Industri, 2(2), 138-147. https://doi.org/10.24014/jti.v2i2.5100
Mustika, M. (2019). Penerapan Teknologi Digital Marketing Untuk Meningkatkan Strategi Pemasaran Snack Tiwul. JSAI (Journal Scientific and Applied Informatics), 2(2), 165-171. https://doi.org/10.36085/jsai.v2i2.352

Prayudi, D., \& Yulistria, R. (2020). Penggunaan Matriks SWOT dan Metode QSPM pada Strategi Pemasaran Jasa Wedding Organizer: Studi Kasus pada UMKM Gosimplywedding Sukabumi. Jurnal Maksipreneur: Manajemen, Koperasi, Dan Entrepreneurship, 9(2), 224-240. https://doi.org/10.30588/jmp.v9i2.516

Purwana, D., Rahmi, R., \& Aditya, S. (2017). Pemanfaatan Digital Marketing Bagi Usaha Mikro, Kecil, Dan Menengah (UMKM) Di Kelurahan Malaka Sari, Duren Sawit. Jurnal Pemberdayaan Masyarakat Madani (JPMM), 1(1), 1-17. https://doi.org/10.21009/jpmm.001.1.01

Puspitasari, N. B., Rumita, R., \& Pratama, G. Y. (2013). Pemilihan Strategi Bisnis dengan Menggunakan QSPM (Quantitative Strategic Planning Matrix) dan Model MAUT (Multi Attribute Utility Theory)(Studi Kasus Pada Sentra Industri Gerabah Kasongan, Bantul, Yogyakarta).J J@TI UNDIP: JURNAL TEKNIK INDUSTRI, 8(3), 171-180. https://doi.org/10.12777/jati.8.3.171-180

Rachmawati, H. M., \& Pratama, A. J. (2017). Analisa Metode Swot Dan Perencanaan Strategi Guna Menentukan Strategi Bisnis Perusahaan Panel Listrik Pada PT. Laksana Panel. Prosiding SNATIF, 701-707. https://jurnal.umk.ac.id/index.php/SNA/articl e/view/1432/0

Setyorini, H., Effendi, M., \& Santoso, I. (2016). Marketing Strategy Analysis Using SWOT Matrix and QSPM (Case Study: WS Restaurant Soekarno Hatta Malang). Industria: Jurnal Teknologi Dan Manajemen Agroindustri, 5(1), 46-53. https://doi.org/10.21776/ub.industria.2016.0 05.01 .6

Sulaksono, J. (2020). Peranan Digital Marketing Bagi Usaha Mikro, Kecil, Dan Menengah (Umkm) Desa Tales Kabupaten Kediri. Generation Journal, 4(1), 41-47. https://doi.org/10.29407/gj.v4i1.13906

Tambunan, W., Amelia, T., \& Priyana, F. P. (2019). Perencanaan Strategi Pemasaran Usaha Mikro Kecil dan Menengah Manis Bakery. Jurnal INTECH Teknik Industri Universitas Serang Raya, 5(1), 23-34. https://doi.org/10.30656/intech.v5i1.1067

Tarigan, H. B., Mahadewi, N. P. E., \& Sudana, I. P. (2015). Strategi Pemasaran Paket Wisata 
PT. UBS Tour and Travel di Denpasar Bali. Jurnal IPTA I, 3(2), 86-91. https://ojs.unud.ac.id/index.php/pariwisata/a rticle/view/22846

Wicaksono, A. (2018). Strategi Pemasaran dengan menggunakan Analisis SWOT Tanpa Skala Industri Pada PT X Di Jakarta. Jurnal Manajemen Industri Dan Logistik,
1(2), 192-201. https://doi.org/10.30988/jmil.v1i2.19 Zulkarnaen, H. O., \& Sutopo, S. (2013). Analisis Strategi Pemasaran Pada Usaha Kecil Menengah (UKM) Makanan Ringan (Studi Penelitian UKM Snack Barokah di Solo). Thesis. Universitas Diponegoro. http://eprints.undip.ac.id/40138/ 